\title{
Barn som pårørende anno 2018
}

\section{Camilla Lauritzen}

f. 1974

Professor, Regionalt Kunnskapssenter om Barn og Unge, Psykisk helse og Barnevern (RKBU Nord), Det Helsevitenskapelige Fakultet, UiT - Norges Arktiske Universitet camilla.lauritzen@uit.no

Psykisk helsearbeid med voksne pasienter må også handle om barna deres. Det høres så enkelt ut - hvorfor er det ikke det?

Jeg har jobbet med temaet barn som pårørende i tiår nå. I løpet av de ti årene har det skjedd mye, og samtidig ganske lite. La meg starte med å si litt om hva vi mener med barn som pårørende. Dersom du har jobbet i helsesektoren i de siste årene, så har du nok hørt det bli snakket om.

Med barn som pårørende mener man alle barn under 18 som har foreldre som blir alvorlig syke; det være seg alvorlig somatisk sykdom som kreft, alvorlig skade, psykisk sykdom eller rusmisbruk. Vi snakker om mange barn, altså. Bare innenfor psykisk helse anslår man at om lag 410000 barn har foreldre med diagnostiserbare psykiske lidelser fra mildt til alvorlig symptomtrykk) hvorav 115000 er av alvorlig karakter (Torvik og Rognmo, 2011).

En av de viktigste hendelsene i løpet av det siste tiåret var endringen i helsepersonelloven som kom i 2010. Der ble helsepersonells plikt til å bidra til å ivareta mindreårige barn som pårørende gjort tydeligere. Essensen i denne endringen handler om kartlegging. Etter 2010 skal helsepersonell som yter helsehjelp til voksne pasienter avklare om pasienten har mindreårige barn. I tillegg skal man kartlegge hvilke informasjons- eller oppfølgingsbehov familien har. På bakgrunn av det som avdekkes i kartleggingen, skal helsepersonell også ivareta det behovet for informasjon og oppfølging som mindreårige barn kan ha som følge av sykdommen til foreldrene. I 2017 ble loven også utvidet til å omfatte søsken og barn som blir etterlatte når foreldre eller søsken dør (Helse- og omsorgsdepartementet, 2010). 
Denne lovendringen var svært viktig. Den etablerte en lovfestet rett til å bli sett og ivaretatt når de viktigste personene i livet ikke lenger kan forventes å fungere optimalt i foreldrerollen. Det er jo slik at det å bli syk i seg selv ikke nødvendigvis fører til at du blir en dårlig forelder, men vi vet mye om at foreldreferdigheter svekkes når man blir alvorlig syk. Foreldre som strever med sin psykiske helse har ofte nok med seg selv, og mange kan ha skylapper for hvor mye det påvirker barna. Den gamle tankegangen om at det de ikke vet har de ikke vondt av, lever i beste velgående der ute, og mange tenker at man skal skjerme barna for de voksnes problemer. I mange tilfeller kan det virke mot sin hensikt, fordi barn ofte får med seg mer enn vi tror. Der det ikke blir gitt forklaringer på hva som foregår i familien, ser man ofte at barn utvikler stor grad av skam- og skyldfølelse og lager seg forklaringer som ikke har rot i virkeligheten. Mange foreldre med psykiske helseplager kan ha behov for hjelp til å snakke med barna sine om det som skjer, for eksempel til å forklare hva psykisk sykdom er og til å tydeliggjøre at det ikke er barnets skyld at foreldrene har problemer. Helsepersonell er i en unik posisjon til å kunne bistå familiene med slike samtaler.

Foreldres psykiske lidelser betraktes som en sentral risikofaktor som kan ha stor innvirkning på barns utvikling og trivsel. Studier viser blant annet at disse foreldrene har flere problemer i samspill med barna sine, og at de er mindre involvert i barnas liv (Kowalenko, Mares, Newman, Williams, Powrie \& vanDoesum, 2012; Murray \& Cooper, 1997; Van Doesum, 2007). I tillegg kan hverdagslivet bli vanskelig å mestre. Det kan handle om små ting som å klare å møte opp på avslutning på skolen, eller å kjøre til fotballkampen og stå ved gressmatta og heie, eller å klare å holde boligen i orden og ta klesvasken. For mange barn blir det skummelt å ta med venner hjem, fordi de ikke har kontroll på hvordan stemningen og tilstanden i hjemmet er. Et annet kjent scenario er at foreldrenes humør blir påvirket, og dette kan gi utslag $\mathrm{i}$ «kortere lunte». Da kan det fort utvikle seg i en negativ spiral der man gradvis kjefter mer og skaper avstand mellom seg og barnet sitt. Psykiske helseutfordringer hos foreldre kan altså føre til dårligere familiefungering og lavere grad av oppfølging av barna, men også lede videre til omsorgssvikt og mishandling (Bauer \& Webster-Stratton, 2006; Foster et al., 2008; Gardner et al., 1999; Granic \& Patterson, 2006; Sidebotham \& Golding, 2001). 
Forskningsmessig synes det av og til som om vi tar ett skritt fram og to tilbake, eller rett og slett står på stedet hvil. For ikke så lenge siden var det en sak på forskning.no om at forskere i stor utstrekning forsker på det vi allerede vet (Jære, 2018). Og er det noe vi allerede har god og bred kunnskap om. så er det om hvordan det er å vokse opp med foreldre som av en eller annen grunn ikke fungerer slik de skal. Vi vet en del om hvilke styrker og svakheter disse barna oppgir at de har (Drost, van der Krieke, Sytema, \& Schippers, 2016; Grove, Reupert \& Maybery, 2015). Vi vet at oppvekst med rusmisbrukende foreldre fører til at mange barn utvikler en sterk følelse av skam og skyld. Vi vet at psykiske helseproblemer hos foreldre kan gjøre at barna utvikler en rekke problemer selv, alt fra spiseforstyrrelser til selvskading til atferdsvansker. Vi vet at det å vokse opp med foreldre som bruker vold kan føre til traumer. Vi vet også at selvmordsforsøk hos foreldre skaper engstelige barn, at deprimerte foreldre ofte får deprimerte barn eller at barna utvikler depresjon når de selv blir voksne (Beardslee, Versage \& Velde, 2002; Goodman \& Gottlieb, 2002; Goodman, Rouse \& Connell, 2011; Weissman, Gammon \& John, 1987; Cicchetti et al., 1998; Hipwell, Goossens, Melhuish \& Kumar, 2000; Reupert \& Maybery, 2007; Sidebotham \& Golding, 2001; Brennan et al., 2000; Christensen \& Bilenberg, 2000, Poon et al., 2000, Loukas et al., 2000; Weissman et al., 1987; Webb, Pickles, Appleby, Mortensen \& Abel, 2007).

Selv om vi har tallrike studier som viser alvorlige konsekvenser for barn som pårørende, synes forskningen å stå litt på stedet hvil. Det utvikles forskningsprosjekter der man har som mål å ta rede på hvordan barna har det selv om vi vet mye om dette allerede. Gjennomgangstonen er at barnas stemmer må bli hørt, og at vi må ta rede på hva barn og unge tenker om å vokse opp med syke foreldre. Forstå meg rett, det er utrolig viktig at barn og unge får komme til orde og at noen snakker med dem om det som skjer i livet deres. Dette er imidlertid først og fremst en oppgave for helsepersonell. Det er min oppriktige mening at vi som forsker på dette nå må komme oss et steg videre. Som forsker er det frustrerende å se at den store potten med forskningsmidler går til å belyse spørsmål vi vet svaret på. Slik jeg ser det er det på høy tid å gjøre noe konkret med det vi allerede vet om konsekvenser for barn som er pårørende. 
Jeg vet ikke hvorfor vi har blitt stående litt fast forskningsmessig. Kanskje er det fordi det appellerer til medmennesket i oss å fortsette å grave i hvordan det er å ha en syk forelder? Det er jo så viktig, sier vi. Brukermedvirkning i forskningen er veldig i tiden, og studier der man har tematisert dette vinner oftere fram i kampen om midler (Forskningsbarometeret, 2018). Nå er jeg absolutt for brukermedvirkning og tror vi har mye å vinne på å bedre inkludere barn i forskning som angår dem. Jeg bare mener at vi må komme oss videre fra spørsmål om hvordan har de det, til å finne ut hva som best kan hjelpe.

Et annet område der utviklingen går svært sakte er knyttet til arbeidet med å endre praksisen i sykehusene slik at alle pasienter som har barn blir kartlagt og får tilbud om støttende tiltak. Mye har vært prøvd ut i hele Norge og i utlandet også. Når disse innsatsene evalueres ser vi dessverre at man ikke helt lykkes i å implementere kartlegging av alle pasienter med påfølgende tilbud om oppfølging (Lauritzen, Reedtz, Rognmo, Nilsen \& Walstad, 2018; Lauritzen, Kolmannskog \& Iversen, 2018; Ruud og kolleger, 2015). Også i utlandet sliter man med å få på plass systematiske rutiner som sørger for ivaretakelse av alle barn som pårørende (Laletas m.fl., 2015, 2018; Grant m.fl., 2018).

Hvorfor det er så vanskelig å endre praksis i helsetjenestene, er et spørsmål som har mange svar. En forklaring kan være knyttet til manglende bevissthet om at voksne pasienter svært ofte har barn og at barna er i risiko for å utvikle sosiale og/eller psykiske problemer selv (Maybery \& Reupert, 2006). Videre ser vi at helsepersonell som arbeider med voksne kan føle seg usikre på å drøfte barneomsorg og til å inkludere pasientenes barn i behandlingen, fordi de ikke er utdannet til dette (Lauritzen \& Reedtz, 2013). En annen forklaring er knyttet til at finansiering av helsetjenestene er basert på klientkontakt, og ettersom barna til pasientene ikke er klienter, gir ikke samtaler med familiene økonomisk uttelling etter dagens finansieringsordning (Ogden, 2012, s. 120). Vi må heller ikke glemme at tid og ressurser i klinisk arbeid er begrensede goder, hvilket gjør at helsepersonell ikke har eller tar seg tid til å kartlegge om pasientene har barn og barnas behov.

En annen viktig utfordring er knyttet til tilgjengelige tiltak for barn som pårørende. Det finnes faktisk en del tiltak som er godt utprøvd i Norge og andre land, og som vi 
gjennom forskning vet har potensiale til å kunne forebygge at barn som pårørende utvikler store og langvarige psykiske helseproblemer. Eksempler på tiltak som har god forskingsdokumentasjon, er foreldreveiledningstiltak som De utrolige årene eller TIBIR, eller samtaletiltak for barn og familier som SMIL og Barneperspektivsamtalen (se databasen Ungsinn.no for flere). Likevel ser vi ofte at disse tiltakene ikke tas i bruk ute i tjenestene, og man går i gang med nye tiltak der det ikke foreligger noe slags forskning på om tiltaket virker eller ikke. Det hersker en misforståelse der ute om de såkalte evidensbaserte tiltakene. Mange synes å tro at evidensbaserte tiltak betyr at man blindt skal følge en «oppskrift» og legge bort alt faglig skjønn. Dette er bare en myte. At et tiltak har evidens betyr bare at det har blitt forsket på og at man har funnet ut at de virker i forhold til målsetningene. At et tiltak har en fremgangsmåte utelukker selvsagt aldri faglig skjønn.

Selv om vi nå har erfart at det er mange utfordringer knyttet til å bedre praksis rundt barn som pårørende, endrer ikke dette utgangspunktet, nemlig at svært mange barn har behov for å bli sett og få støtte når foreldrene blir syke. Men, for å komme i posisjon til å hjelpe barn som er pårørende, så må kartlegging i tjenestene komme på plass. Det er åtte år siden helsepersonelloven ble endret og dette ble obligatorisk, og likevel viser gjennomgang av journaler at helsepersonell fremdeles ikke systematisk undersøker om pasienter har barn (Lauritzen m.fl., 2018). Man kan bli litt matt av tregheten i arbeidet med å etablere ny praksis, men når flere studier av journaler viser hvor lite som faktisk gjøres i sykehusene for å ivareta barn som pårørende, så er det viktig å stoppe opp og ta disse funnene inn over seg. Når forskningen viser at vi står på stedet hvil, ville det være både uredelig og uetisk å late som noe annet. I stedet må vi ta med oss det forskningen viser og justere kursen. Vi skylder de usynlige barna å slåss for dem til de blir sett av de fagfolkene som har lovfestet plikt til å se dem.

Er situasjonen for barn som pårørende helsvart, da? Nei, heldigvis er det ikke bare motgang og utfordringer å vise til når vi snakker om barn som pårørende. Det finnes både enkeltaktører i fagmiljøene og større aktører som jobber systematisk med å fremme praksisendringer for barn som pårørende. Voksne for Barn er en viktig organisasjon som har jobbet for å fremme gode oppvekstvilkår og psykisk helse gjennom en årrekke. Voksne for barn tilbyr kurs i samtaler med barn som pårørende, $\mathrm{i}$ tillegg til mye annet. I tillegg har vi i Norge et nasjonalt kompetansenettverk for barn 
som pårørende som heter BarnsBeste. BarnsBeste tilbyr blant annet rådgivning og utvikler ressurser for fagfolk. Disse to aktørene er viktige støttespillere for fagfolk i praksisfeltet. Jeg kunne nevnt flere, men la oss gå litt videre.

Hva er drømmesituasjonen for arbeidet med barn som pårørende? Slik jeg ser det, er drømmesituasjonen at alle voksne pasienter som mottar helsehjelp kartlegges med tanke på å fastslå om de har barn og hvilke behov familien har for informasjon og støtte. Altså akkurat det som var intensjonen med lovgivningen, men som det har vist seg å være så utfordrende å få til i praksis.

Så hvordan kan vi komme oss til denne drømmesituasjonen? Her er det flere ting vi må ta på alvor. For det første: vi må komme oss videre fra grunnlagsstudiene. Nå er det på tide å brette opp ermene og ta i bruk det barn og unge har fortalt oss $\mathrm{i}$ en årrekke. Vi kjenner utfordringene knyttet til å ha foreldre som er syke, nå må vi fokusere på hjelpetiltak som fungerer. I forlengelsen av dette vil jeg også si at vi må slutte å finne opp kruttet om og om igjen. Det kan nesten virke som «alle» skal lage sin egen variant av tiltak som allerede finnes og er godt beskrevet. Vi må slutte å lage nesten identiske tiltak men med nye navn - la oss ta i bruk de tiltakene vi allerede vet har effekt. Ungsinn.no er en nettside som tilbyr oversikt og evaluering av slike tiltak, og som fagfolk kan ha god hjelp i å se til når arbeid med barn og familier skal planlegges.

Og så må vi selvsagt evaluere det vi holder på med. Virker det slik det var tenkt? Virker deler av innsatsen? Hva er det som i så fall virker? Et viktig spørsmål vi kan stille oss i det videre arbeidet er: Hvordan kan vi videreutvikle tiltakene våre slik at de blir best mulig tilpasset akkurat denne gruppen barn?

Jeg syns også at myndighetene kan reise sterkere krav om at denne delen av helsepersonelloven må følges. Helseforetakene bør måles på om de etterfølger denne loven - hvorfor er det ingen som stiller krav til at paragrafene følges? En løsning kunne jo være å gjøre det vanskeligere å komme seg videre i elektroniske pasientjournaler dersom man ikke har fylt ut svar på spørsmål om pasienten har mindreårige barn. Vi kan ikke akseptere at dette forblir en «sovende» paragraf. 
Studier har vist at helsepersonell har positive holdninger til å jobbe med barn som pårørende, og de har også kunnskaper om konsekvenser for barn når foreldrene blir syke (Lauritzen m.fl., 2014). Hvordan kan vi få til å bygge bro mellom denne kunnskapen og det som faktisk gjøres i praksis?

Hva mener du skal til? Flere ressurser? Andre organiseringer av arbeidet? Mer fokus på innholdet i rollen som Barneansvarlig, som per i dag er en rolle det i stor grad er opp til hver enkelt avdeling å definere? Jeg har dessverre ikke et enkelt og greit svar på dette selv. Dette er et arbeid som mange ulike aktører må samarbeide om å dra fremover; klinikere, forskere, familiene selv og myndighetene. Vi må ikke miste motet selv om det har vært litt utfordrende.

Enda godt vi ikke har tenkt å gi oss med det første! Det er mange ting på gang. Sykehusene arrangerer fagdager, det forskes på bedre løsninger, det tilbys kurs, konferanser og opplæring, og bevisstheten om barn som pårørende er forhåpentligvis $\emptyset$ kende. I 2019 arrangeres det en stor internasjonal konferanse i Oslo der praktikere og forskere på feltet fra hele verden skal møtes med et felles mål om å drive arbeidet fremover (konferansen heter «It takes a Village 2019»).

En dag ser vi kanskje med undring tilbake på dette tidsrommet der vi strevde så mye med å endre praksis slik at barna til voksne pasienter blir sett og ivaretatt. For det kan jo ikke være umulig ut å få til, eller? 


\section{Referanser}

Bauer, N. S., \& Webster-Stratton, C. (2006). Prevention of behavioral disorders in primary care. Current Opinion in Pediatrics, 18, 654-660.

Beardslee, W. R., Versage, E. M., Velde, P. V. d., Swatling, S., \& Hoke, L. (2002). The effects of parental dysfunction on children, in Preventing depression in children through resiliency promotion: The Preventive Intervention Project, (pp. 71-86). New York, NY: Kluwer Academic/Plenum Publishers; US.

Drost, L. M., van der Krieke, L., Sytema, S. og Schippers, G. M. (2016). SelfExpressed Strengths and Resources of Children of Parents With a Mental Illness: A Systematic Review. International Journal of Mental Health Nursing, 25, 102-115.

Forskningsbarometeret (2018). Norge dårligst i verden på å investere i forskning. Forskning.no. Nedlastet fra: https://forskning.no/forskningsfinansiering/2018/05/norgedarligst-i-norden-pa-investere-i-forskning

Foster, E. M., Prinz, R. J., Sanders, M. R., \& Shapiro, C. J. (2008). The costs of a public health infrastructure for delivering parenting and family support. Children and Youth Services Review, 30, 493-501.

Gardner, F., Sonuga-Barke, E. J. S., \& Sayal, K. (1999). Parents Anticipating Misbehaviour: An Observational Study of Strategies Parents Use to Prevent Conflict with Behaviour Problem Children. The Journal of Child Psychology and Psychiatry and Allied Disciplines, 40, 1185-1196.

Goodman, S. H., \& Gotlib, I. H. (2002). Children of depressed parents: Mechanisms of risk and implications for treatment. Washington, DC: American Psychological Association; US.

Goodman, S. H., Rouse, M. H., Connell, A. M., Broth, M. R., Hall, C. M., \& Heyward, D. (2011). Maternal depression and child psychopathology: A metaanalytic review. Clinical Child and Family Psychology Review, 14, 1-27.

Granic, I., \& Patterson, G. R. (2006). Toward a comprehensive model of antisocial development: A dynamic systems approach. Psychological Review, 113, 101-131.

Grant, A., Reupert, A., Maybery, D. \& Goodyear, M. (2018). Predictors and enablers of mental health nurses' family-focused practice. International Journal of Mental Health Nursing.

Grove, C., Reupert, A. og Maybery, D. (2015). Gaining Knowledge About Parental Mental Illness: How Does it Empower Children? Child and Family Social Work, 20, 377-386.

Helse- og omsorgsdepartementet (2010). Helsepersonelloven. Nedlastet fra https://lovdata.no/dokument/NL/lov/1999-07-02-64?q=helsepersonelloven 
Jære, L. (2018). Forskere bruker mye tid på det vi allerede vet. Forskning.no.

Nedlastet fra: https://forskning.no/2018/05/forsker-pa-det-vi-allerede-vet/produsert-

og-finansiert-av/de-nasjonale-forskningsetiske-komiteene

Kowalenko, N.M., Mares, S.P., Newman, L.K., Williams, A.E.S., Powrie, R.M., \& Van Doesum, K.T.M. (2012). Family Matters: Infants, Toddlers and Preschoolers of parents affected by mental illness. Early interventions targeting adverse influences on young children and their parents can improve children's outcomes. Medical Journal of Australia Open. doi: 10.5694/mjao12.10553

Laletas, S., Goodyear, M. J. \& Reupert, A. E. (2018). Parental mental illness: Crosssectional analysis of family focused practice within the early childhood sector Journal of Child and Family Studies. 27, 5, p. 1650-1660.

Laletas, S., Reupert, A., Goodyear, M. og Morgan, B. (2015). Pathways of Care: Targeting the Early Childhood Sector for Early Intervention. Advances in Mental Health, 13(2), 139-152.

Lauritzen, C., Kolmannskog, A.B., \& Iversen, A.C. (2018). Family assessment conversations as a tool to support families affected by parental mental illness: a retrospective review of electronic patient journals. International Journal of Mental Health Systems, 12.

Lauritzen, C., \& Reedtz, C. (2013). Support for children of mental health service users in Norway. Mental Health Practice, 16, 12-18.

Lauritzen, C., Reedtz, C., Rognmo, K., Nilsen, M.A., \& Walstad, A. (In press). Identification and support for children of mentally ill parents: A five year follow-up study of adult mental health services. Frontiers of Psychiatry - Public Mental Health.

Lauritzen, C., Reedtz, C., Martinussen, M.,\& van Doesum, K. (2014).

Implementing new routines in adult mental health care to identify and support children of mentally ill parents. BMC Health Services Research, 14:58.

Maybery, D., \& Reupert, A. (2006). Workforce capacity to respond to children whose parents have a mental illness. Australian and New Zealand Journal of Psychiatry, 40, $657-664$.

Murray, L. \& Cooper, P. (1997). Effects of postnatal depression on infant development. Archives of Disease in Childhood, 77, 99-101.

Ogden, T. (2012). Evidensbasert praksis i arbeidet med barn og unge. Oslo: Gyldendal Akademisk.

Ruud, T., Birkeland, B., Faugli, A., Hagen, K. A., Hellmann, A., Hilsen, M.,. Weimand, B.M. (2015). Barn som pårørende - Resultater fra en multisenterstudie: Akershus universitetssykehus HF i samarbeid med Nordlandssykehuset HF Helse Stavanger HF (Stavanger universitetssykehus) Rogaland A-senter Sørlandet sykehus 
HF Vestre Viken HF Regionsenter for barn og unges psykiske helse Helseregion Øst og Sør BarnsBeste.

Sidebotham, P., \& Golding, J. (2001). Child maltreatment in the "Children of the Nineties": A longitudinal study of parental risk factors. Child Abuse \& Neglect, 25, $1177-1200$.

Torvik, F. A. og Rognmo, K. (2011). Barn av foreldre med psykiske lidelser eller alkoholmisbruk: omfang og konsekvenser. Oslo: Nasjonalt

Folkehelseinstitutt. Rapport nr.: 2011:4.

Van Doesum, K.T.M. (2007). An early preventive intervention for depressed mothers and their infants, its efficacy and predictors of maternal sensitivity. RIAGG IJ selland Deventer.

Webb, R. T., Pickles, A. R., Appleby, L., Mortensen, P. B., \& Abel, K. M. (2007). Death by unnatural causes during childhood and early adulthood in offspring of psychiatric inpatients. Archives of general psychiatry, 64(3), 345-52. doi: 10.1001/archpsyc.64.3.345. 